\title{
STENOFI. \\ RESEARCH ARTICLE \\ Influence of rainfall and temperature on the spermatogenesis of Leptodactylus macrosternum (Anura: Leptodactylidae)
}

\author{
Marcio F. Chaves ${ }^{1,5}$, Geraldo J.B. de Moura ${ }^{2}$, Fernanda das C.M.A. Tenório ${ }^{3}$, Josemberg da S. Baptista ${ }^{4}$, \\ Clovis J.C. Lapa Neto ${ }^{5}$, Valeria W. Texeira ${ }^{5}$, Álvaro A.C. Texeira ${ }^{5}$
}

\begin{abstract}
'Unidade Acadêmica de Biologia e Química, Centro de Educação e Saúde, Universidade Federal de Campina Grande. Olho d'Áqua da Bica, 58175-000 Cuité, PB, Brazil.

${ }^{2}$ Departamento de Biologia, Universidade Federal Rural de Pernambuco. Rua Dom Manoel de Medeiros, Dois Irmãos, 52171-900 Recife, PE, Brazil.

${ }^{3}$ Núcleo de Ciências da Vida, Departamento de Morfologia, Universidade Federal de Pernambuco. Rodovia BR-104, km 59, Nova Caruaru, 55002-970 Caruaru, PE, Brazil.

${ }^{4}$ Departamento de Morfologia e Fisiologia Animal, Universidade Federal Rural de Pernambuco. Rua Dom Manoel de Medeiros, Dois Irmãos, 52171-900 Recife, PE, Brazil.

${ }^{5}$ Departamento de Morfologia, Universidade Federal do Espírito Santo. Avenida Marechal Campos 1468, Maruípe, 29040-090 Vitória, ES, Brazil.

Corresponding author: Marcio Frazão Chaves (marciochaves@ufcg.edu.br)
\end{abstract}

http://zoobank.org/29EBFF54-4BFF-4419-BDA8-4D63A573D6F7

\begin{abstract}
In the semi-arid environment, the reproductive success of anurans depends on adaptations in their life cycle, which synchronizes with ideal environmental conditions to maximize the number of offspring. In this study changes in the histological and morphometric aspects of the testes of Leptodactylus macrosternum Miranda-Ribeiro, 1926 are characterized, to evaluate the influence of rainfall and temperature on them. Specimens were collected at Horto Florestal Olho d'Água da Bica - HFOB $\left(06^{\circ} 49^{\prime} 20^{\prime \prime} \mathrm{S}, 36^{\circ} 15^{\prime} 85^{\prime \prime} \mathrm{W}\right)$ area, municipality of Cuité, state of Paraíba, Brazil. Search for specimens was active, happened at night, and amounted to 15 days from January to December 2013. The densities of spermatids (primary and secondary), sperm and area of the seminiferous locules of the testes were registered. The influence of climate variables (rainfall and temperature) on the density of primary and secondary spermatids, sperm and locular area were verified using Simple Linear Regression. Primary spermatids had the lowest density in July $\left(57.90 \pm 51.54 \mathrm{~mm}^{2}\right)$, with a peak in November $\left(300.32 \pm 117.35 \mathrm{~mm}^{2}\right)$; secondary spermatids had the lowest density in December $\left(287.87 \pm 79.05 \mathrm{~mm}^{2}\right)$, with a peak in May $\left(135,727.00 \pm 301.13 \mathrm{~mm}^{2}\right)$; sperm was in the lowest density in July $\left(237.37 \pm 121.10 \mathrm{~mm}^{2}\right)$, with a peak in June $(2,270.45 \pm$ $\left.602.62 \mathrm{~mm}^{2}\right)$ and the locular area had the lowest density in December $\left(40,292.9 \pm 8,174.20 \mu \mathrm{m}^{2}\right)$ and highest density in June $\left(338,875.01 \pm 2,262.10 \mu \mathrm{m}^{2}\right)$. A notable decrease in sperm density was evident between June and July. That, associated with the observation of a larger locular area in June, allowed us to identify as June as the peak of spermatogenesis and the following month as the most potentially reproductive. The density of secondary spermatids $(r=0.02)$, sperm $(r=0.21)$ and locular area $(r=0.01)$ showed dependency on rainfall whereas only sperm $(r=0.09)$ showed dependency on temperature. Therefore, we can state that the reproductive cycle of $L$. macrosternum is potentially continuous, with a reproductive peak in July.
\end{abstract}

KEY WORDS. Anuran, semi-arid, spermatids, spermatozoa.

\section{INTRODUCTION}

In anurans, the control of spermatogenesis and consequently the reproductive cycles, are mediated by the interaction between the animal's endogenous rhythms and the influence of environmental factors (Sasso-Cerri et al. 2004). Among the latter, temperature and rainfall are the main climatic factors influencing the reproductive cycles of anurans (Cardoso and Martins 1987).

The reproductive cycles of anurans are classified based on the sum of the histological features of their gonads and their 
behavioral patterns as: continuous, potentially continuous and discontinuous (Lofts 1974). The discontinuous cycle, typical of temperate climate zones, is characterized by a discreet breeding period with pronounced changes in gonad size, gamete production and accessory sexual structures. Continuous and potentially continuous cycles, typical of tropical regions, are characterized by the constant production of gametes. However, in the latter, there is a partial interruption in gametogenesis during certain periods.

Typical of semi-arid regions, potentially continuous cycles are determined by irregular and limited rainfall (Duellman and Trueb 1994, Moore et al. 2005, Sasso-Cerri et al. 2004) and are thus limited to a short period during the year (Bertoluci and Rodrigues 2002, Rodrigues 2003, Prado and Uetanabaro 2000). In semi-arid regions, rainfall and temperature influence the maturation of the testes and consequent production of sperm (Sasso-Cerri et al. 2004), coinciding with the higher peaks of sex hormones, either for a short period (explosive reproduction) or permanently (prolonged reproduction) (Wilczynski et al. 2005). Rainfall and temperature also determine the timeline of the development of secondary sexual characteristics and the beginning and maintenance of sexual behaviors in anurans (Moore et al. 2005).

Leptodactylus macrosternum Miranda-Ribeiro, 1926 is widely distributed in semi-arid environments. It displays a generalist behavior and is well adapted to disturbed areas (De La Ivã and Maldonado 1999). The species is hunted for its meat (Alves et al. 2009) and is sporadically reared as an alternative to exotic species in local raniculture - e.g., Lithobates catesbiana (Shaw, 1802) (Cunha and Delariva 2009). Furthermore, due to its commercial value, abundance and easy detectability, L. macrosternum has been adopted as a biological model. Its biological characteristics make it an ideal subject to test our hypothesis that, in semi-arid regions, rainfall and temperature are the most important regulators of the spermatogenic process in Anuran Amphibians. In this study we characterize the histologic and morphometric aspects of the testes of L. macrosternum and evaluate the influence of rainfall and temperature on the parameters tested.

\section{MATERIAL AND METHODS}

Night expeditions were undertaken every 15 days, from January to December 2013, to verify the reproductive activity of L. macrosternum males. According to Arzabe (1999), whose work was carried out in the semi-arid environments of the state of Paraíba, anurans subjected to extreme hydric stress present a short and explosive reproductive period. Therefore, to increase our chances of capturing specimens in different stages of spermatogenesis, our collecting expeditions were 15 days apart from one another.

Males of $L$. macrosternum were collected manually at Horto Florestal Olhod'Água da Bica-HFOB $\left(06^{\circ} 49^{\prime} 20^{\prime \prime}\right.$ S, 36 $\left.6^{\circ} 15^{\prime} 85^{\prime \prime} \mathrm{W}\right)$, located in the municipality of Cuité, Paraíba. The area is situated in the Brazilian Caatinga domain and is characterized by its hot, dry climate with temperatures ranging between 17 and $28^{\circ} \mathrm{C}$, an average monthly rainfall of $76.35 \mathrm{~mm}$ and relative humidity of approximately $70 \%$. The hydrography of the Caatinga is peculiar, with temporary rivers, ponds, streams, reservoirs, wetlands and as slope areas from which the sources of water flow. The Horto Florestal encompasses 70 ha of bush and arboreal caatinga (Abrantes et al. 2011).

The monthly weather temperature $\left({ }^{\circ} \mathrm{C}\right)$ and rainfall $(\mathrm{mm})$ data were obtained from the Agência Executiva de Águas do Estado da Paraíba (AESA 2014) database, at the weather station neighboring the sampling location.

The captured males of L. macrosternum were taken to the Biosystematics Amphibian Laboratory (LABAN) of the Universidade Federal de Campina Grande, Cuité Campus, Paraíba, where they were euthanized with an overdose of lidocaine $5 \%$.

The testes were fixed in Bouin solution (a mixture of $71 \%$ picric acid, $24 \%$ pure formaldehyde and $5 \%$ of glacial acetic acid) for 24 hours, then dehydrated in increasing alcohol series (70\%-30 min, 80\%-30 min, 90\%-30 $\mathrm{min}, 95 \% 30 \mathrm{~min}, 100 \%-30 \mathrm{~min}$ and 100\%-30 min) (Hopwood 1990), and later paraffin embedded, sectioned at $5.0 \mu \mathrm{m}$ and stained with hematoxylin and eosin (Robinson and Gray 1990). Qualitative analysis of the slides was conducted in a conventional, trinocular, bench microscope (Olympus AX70, Tokyo, Japan - Department of Morphology, Universidade Federal do Espírito Santo - UFES), coupled to a digital image acquisition system (camera ERc 5s and Axiovision 6.3, Carl Zeiss, Jena, Germany from UFES). The cell types were identified according to work described by Hermosilla et al (1986 and Oliveira et al (2003a, b). For the analysis of the seminiferous locular area, a total of twenty-seven loci were randomly selected (raffled), with three animals being analyzed per month (nine loci each); a total of 162 area measurements (Santos and Oliveira 2007).

Stereological analysis to determine the density of spermatids and spermatozoa was based on the precepts of Mandarin-de-Lacerda (1995 and Weibel (1979). The volume density $(\mathrm{Vv})$ of spermatids and spermatozoa were calculated as they represent excellent cellular models as bioindicators of the sexual maturation stage of the individuals. The sample calculation was performed with the use of the Hally (1964) formula and appropriately corrected to the result representing the stereological principles (Mandarim-de-Lacerda 1995). Lastly, to measure density profiles $\left(Q_{A}\right.$, primary and secondary spermatids and spermatozoa), 14, 5 and 6 fields were respectively numbered in a Test Area (TA) with $0.044 \mathrm{~mm}^{2}$ for each animal per study group. The final result $\left(\mathrm{mm}^{2}\right)$ was obtained using the mean for each profile as well as the following equation: $\mathrm{Q}_{\mathrm{A}}=\Sigma$ profiles/TA

The values for the density of cells in the reproductive lineage and the area of the seminiferous locules were compared between months using the Kruskal-Wallis test and, when necessary, supplemented by the Dunn test.

The dependency between the climate variables (rainfall and temperature), the density of the population of reproductive lineage cells, and the area of the seminiferous locules were 

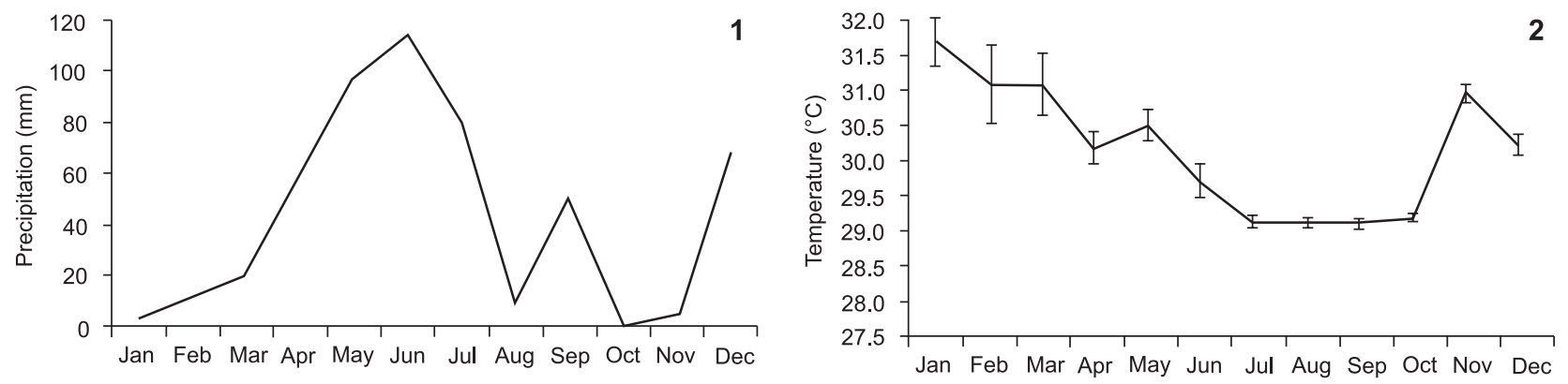

Figures 1-2. Climatological variations in the Horto Florestal Olho d'Água da Bica (HFODB) in the municipality of Cuité, state of Paraíba, Brazil between January and December 2013: (1) total rainfall ( $\mathrm{mm})$; $(2)$ mean and standard deviation of the temperature $\left({ }^{\circ} \mathrm{C}\right)$.

verified using a Simple Linear Regression test. All analyzes were based on Zar (1999) and $\mathrm{p}<0.05$ considered as a reference to assign statistical significance.

\section{RESULTS}

The highest rainfall rates were concentrated from April to July 2013. The lowest rainfall levels at the region were recorded in October and November (Figs 1,2). As for the temperature variation during the sample period, the highest averages were recorded during January, March and November 2013 (Fig. 4).

Twenty-nine L. macrosternum males were collected in May (5 samples), June (11 samples), July (3 samples), August (4 samples), November (4 samples) and December (2 samples) 2013, coinciding with rainfall in the region. Between January and April, and September and October 2013, no individuals of L. macrosternum were found during field trips.

All cell types in the testes of L. macrosternum collected during the sample period were easily verified, with each locule featuring multiple cysts of spermatogenic cells (Fig. 3). Each cyst appeared as a group of germ cells in the same state of differentiation. By delimiting the locules, it was possible to observe the tunica albuginea (Fig. 3, TA), and the mediastinal region at the center of the testicular structure, (Fig. 3, Med). Both structures are formed by connective tissue.

Primary spermatogonia (Fig. 5, SG1), were recorded as cells located in the locular periphery, bordering the tunica albuginea and presenting granular chromatin. Secondary spermatogonia (Fig. 5, SG2) presented a more intense color in comparison with the other cysts, with cells situated immediately after the primary spermatogonia, directing towards the lumen of the seminiferous locule. Both cell types were similar in size.

Primary spermatocytes (Fig. 4, Sp1) were presented as large cells, although smaller than the primary spermatogonia, and had looser chromatin. Secondary spermatocytes (Fig. 5, Sp2) were slightly smaller than the aforementioned cells, with a denser nucleus and large eosinophilic cytoplasm area around it.
Table 1. Monthly values (mean and standard error) for density of primary spermatids (St1), secondary spermatids (St2), sperm (Ez) $\left(\mathrm{mm}^{2}\right)$ and locular area $\left(\mu \mathrm{m}^{2}\right)$ of the testes of Leptodactylus macrosternum species collected in the HFOB area, municipality of Cuité, state of Paraíba, Brazil, in the period from May to December 2013. * Significant differences ( $p<0.05$, Kruskal-Wallis).

\begin{tabular}{ccccc}
\hline & St1 & St2 & Ez & Locular Area \\
\hline May & $176.29 \pm 46.64$ & $1357.27 \pm 30113^{*}$ & $1121.97 \pm 189.2^{*}$ & $227688.7 \pm 1274.1$ \\
Jun & $93.18 \pm 58.35$ & $1301.81 \pm 117.64^{*}$ & $2270.45 \pm 602.62^{*}$ & $338875.01 \pm 226.1^{*}$ \\
Jul & $57.90 \pm 51.54^{*}$ & $633.33 \pm 619.74$ & $237.37 \pm 121.1^{*}$ & $96968.4 \pm 464.2^{*}$ \\
Aug & $83.19 \pm 37.12$ & $770.45 \pm 298.04$ & $1007.57 \pm 370.52$ & $206367.2 \pm 719.3$ \\
Nov & $300.32 \pm 117.35^{*}$ & $628.4 \pm 3090.36$ & $602.27 \pm 212.83$ & $281801.9 \pm 4736.6$ \\
Dec & $139.06 \pm 26.22$ & $287.87 \pm 79.05^{*}$ & $356.06 \pm 179.46$ & $40292.9 \pm 8174.2^{*}$ \\
\hline
\end{tabular}

Table 2. Relations between the density of primary spermatocytes (St1), secondary spermatocytes (St2), sperm (Ez) and the area occupied by the seminiferous locules (LA) in male Leptodactylus macrosternum species in relation to rainfall and temperature in the Horto Florestal Olhod'Água da Bica (HFOB) area in the municipality of Cuité, state of Paraíba, Brazil, in the periods from May to August and November to December 2013. * = Represents significant differences.

\begin{tabular}{ccccc}
\hline & \multicolumn{2}{c}{ Rainfall } & \multicolumn{2}{c}{ Temperature } \\
\cline { 2 - 5 } & $\mathrm{r}$ & $\mathrm{p}$ & $\mathrm{r}$ & $\mathrm{p}$ \\
\hline St1 & 0.03 & 0.40 & 0.01 & 0.77 \\
St2 & 0.02 & $0.04^{*}$ & 0.05 & 0.20 \\
Ez & 0.21 & $0.04^{*}$ & 0.09 & $0.03^{*}$ \\
AL & 0.01 & $0.04^{*}$ & 0.01 & 0.75 \\
\hline
\end{tabular}

Primary spermatids (Fig. 4, St1) were rounded cells, with a slightly compressed nucleus and somewhat elongated shape. Secondary spermatids (Fig. 4, St2) were cells in which the nucleus undergoes stretching concurrently with a progressive nuclear compaction, crumbling its cystic organization to arrange itself in bundles supported by Sertoli cells, although still being considered as a germinal cyst. The spermatozoa (Figs 5-6, Z) 

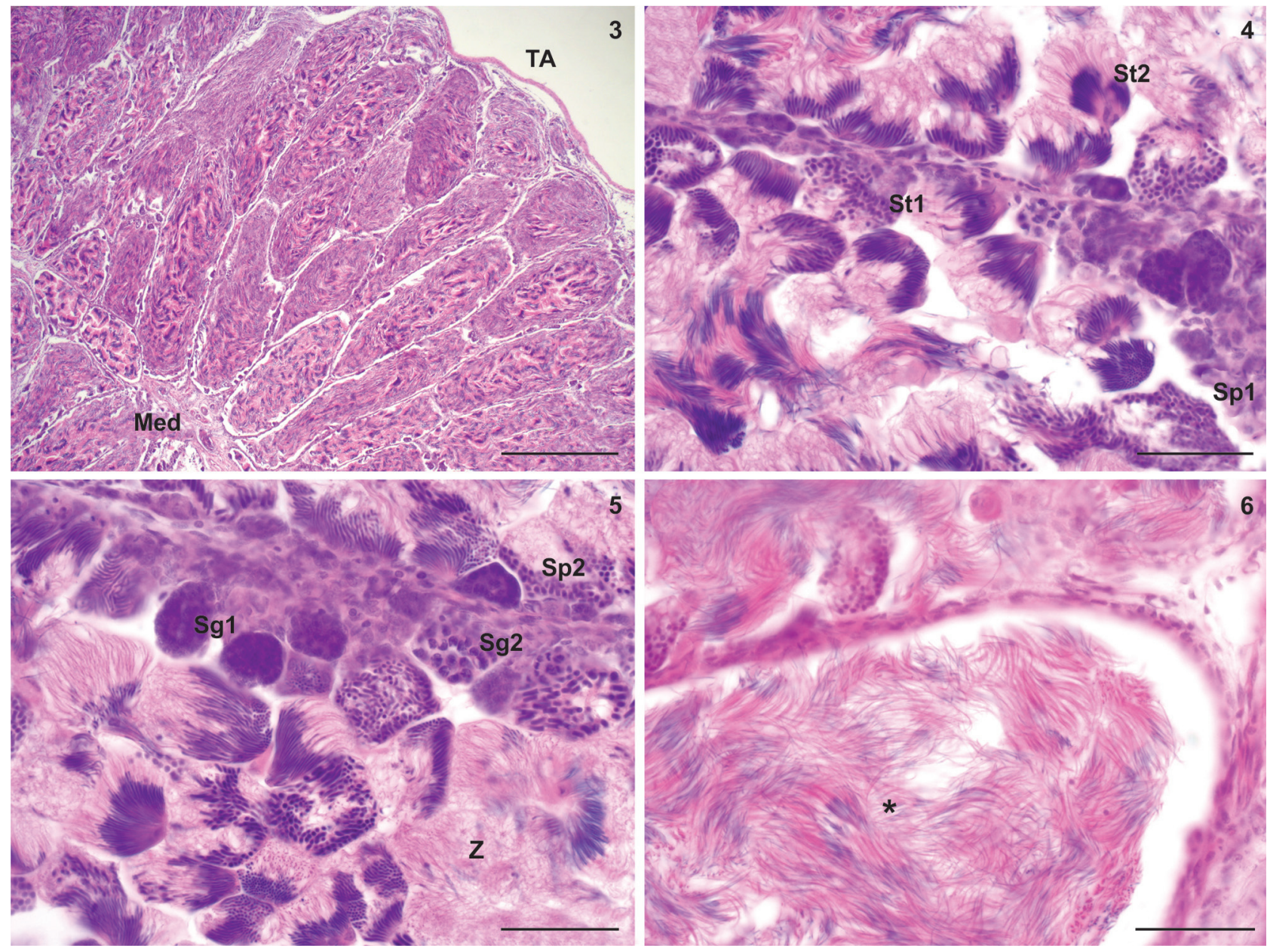

Figures 3-6. Histologic sections of Leptodactylus macrosternum testes, stained in HE, collected between the months of May to August and November to December in the Horto Florestal Olhod'Água da Bica (HFOB) area in the municipality of Cuité, state of Paraíba, Brazil. (3) section at 40x: (TA) tunica albuginea, (Med) mediastinum; (4) section at 40x TA: (St1) primary spermatid, (ST2) secondary spermatid, (Sp1) primary spermatocyte; (5) section at 40x TA: (Sg1) primary spermatogonia, (SG2) secondary spermatogonia, (Sp2) secondary spermatocyte, (Z) sperm; (6) section at 40x: $\left(^{*}\right)$ lumen with sperm. Scale bars: $3=500 \mu \mathrm{m}, 4-6=50 \mu \mathrm{m}$.

appeared as cells characterized by a nuclear compaction and a cytoplasmic reduction, often free in the center of the locules.

The monthly density values of the primary spermatids (St1), secondary spermatids (St2), sperm (Ez) and variation of the locular area of seminiferous tubules showed significant differences ( $p<0.05$, Kruskal-Wallis) over the months of collection (Table 1). The primary spermatid densities (St1) were significantly higher in November $(\mathrm{p}=0.01)$, presenting the lowest significant values in July ( $p=0.03)$. The highest density values for secondary spermatids (St2) were significantly higher in the months of May $(p=0.01)$ and June $(p=0.02)$, whereas the month of December $(\mathrm{p}=0.03)$ showed important lower density values for secondary spermatids (St2). The densities of spermatozoa (Ez) also had the highest significant values in the months of May $(\mathrm{p}=0.04)$ and June $(\mathrm{p}=0.04)$, with meaningful lower values in July $(\mathrm{p}=0.02)$. Regarding the variation of the locular area of the testes of the animals analyzed, those sampled in the month of June showed the highest values $(p=0.01)$. The months of July $(p=0.03)$ and December $(p=0.04)$ presented important lower values for this parameter (Table 1).

As shown in Table 2, significant relationships were only observed between rainfall and the density of secondary spermatocytes (St2) $(\mathrm{R} 2=0.02, \mathrm{p}=0.04)$, sperm density $(\mathrm{Ez})$ $(\mathrm{r}=0.21, \mathrm{p}=0.04)$ and the area occupied by the locules in the seminiferous tubules (AL) $(r=0.01, p=0.04)$ of the testes. The monthly temperature variation in the HFOB area only showed significant relationship with the density of sperm (Ez) $(\mathrm{r}=0.09, \mathrm{p}=0.03)$. 


\section{DISCUSSION}

Our results corroborate the results of Santos and Oliveira (2008), and Leite et al. (2015), who pointed out that, in general, the spermatogenesis process in anurans is cystic, with the organization of germ cells always in the same stage of differentiation. However, the organization of these cysts may vary among different families of anurans (proportion of germ cells present and/or absent) and especially according to the environment where these animals occur, as found by Ferreira et al. (2009) for Dendropsophus nanus (Boulenger, 1889), Pseudis limellum (Cope, 1862) and Pseudis paradoxa (Linnaeus, 1758) of Hylidae and the Leptodactylus chaquensis Cei, 1950 and Leptodactylus podicipinus (Cope, 1862), species of Leptodactilidae from the Pantanal region.

In our findings, the cell characteristics of L. Macrosternum, and the process of spermatogenesis, with variation in the quantities of cysts and especially the spermatozoa within the locules, are similar to L. podicipinus (Prado et al. 2002), L. chaquensis and L. podicipinus (Ferreira et al. 2009), Leptodactylus fuscus (Schneider, 1799) (Maragno and Cechin 2009) and L. chaquensis (Villagra et al. 2014), demonstrating an organizational pattern of germ cells dependent on the seasonal variation of each region.

This morphology, added to a constant production and partial interruption when conditions are unfavorable for reproduction, features an acyclic spermatogenesis process. This appears to be a characteristic of anurans from the Fuscus group of Leptodactylidae (Ferreira et al. 2009), without the observation of all stages of cell differentiation, but with the constant presence of elongated spermatids in a fan-shaped array (Fig. 4) and free spermatozoa (Fig. 6).

Therefore, the characteristics observed in the gametogenic process of $L$. macrosternum classify this type of reproductive cycle as "potentially continuous". This type is typical of seasonal, tropical environments (Lofts 1974). Madelaire and Gomes (2016), studying Rhinella granulose (Spix, 1824), R. jimi (Stevaux, 2002) and Pleurodema diplolister (Peters, 1870) reported that, during the reproductive period in caatinga areas in the state of Rio Grande do Norte, Brazil, male anuran testes presented an advanced stage of maturation, with large germ cysts and beams of free sperm in the cysts' lumen, corroborating the results presented here (Fig. 6).

With regards to the successive histological changes of the analyzed testes, the monthly density values of the primary spermatids (St1), secondary spermatids (St2), sperm (Ez) and variation of locular area of the seminiferous tubules varied significantly between the months of collection, besides portraying a chronological sequence that are compatible with the evolutionary stages of spermatogenesis (Table 1).

In tropical regions of seasonal climate, the reproductive activity of anurans is associated with the rainy season (Santos and Oliveira 2008). This is consistent with the lack of records for the dry period, between January and April, when humidity is very low and rainfall rates fall in the Curimatau macroregion of the state of Paraíba.

In this study, the density of the secondary spermatocytes (St2), the density of sperm (Ez) and the monthly variation in the locular area of the seminiferous tubules (LA) (Table 2) of the testes of the individuals of $L$. macrosternum were significantly correlated with the rates of rainfall in the HFOB area. This corroborates the results of Prado et al. (2002), Prado and Haddad (2003) and Ferreira et al. (2009), who claimed that the reproductive period of Leptodactylidae anurans coincides with the period of higher rainfall in their occurrence areas. This fact may indicate that rainfall in caatinga areas is responsible for stimulating spermatogenesis in anurans of semi-arid environments (Madelaire and Gomes 2016), determining several physiological adaptations, especially those related to basal metabolism, especially to the reproductive cycle (Giaretta et al. 2008).

The monthly temperature variation in the HFOB area only showed significant relationships with sperm density (Ez) (Table 2) and no significant relationships with the remaining parameters. Thus, it is clear that, in semi-arid areas, the physical condition of the environment that interferes the most with the reproductive activity of anurans is rainfall, followed by temperature, determining the most favorable time for reproduction and consequently the spatial distribution of anuran reproduction in semi-arid regions (Duellman and Trueb 1994, Sasso-Cerri et al. 2004, Moore et al. 2005). However, the spermiogenesis and/or spermiation may be correlated with the temperature through the effect of high temperatures on testosterone levels (Kalt 1976, Rastogi et al. 1976). It is known that spermiogenesis lasts no more than 15-45 days, therefore (Rastogi et al. 1976) the effect of and the relationship with temperature on Ez density may be associated with this fact.

Our findings confirm the studies of Prado Uetanabaro (2000), Bertoluci and Rodrigues (2002), and Rodrigues (2003), and allow us to conclude that in environments where seasonality is significant, animals are reproductively active for two or three months during the year, depending on the rainfall peak, and consequently on the availability of reproductive sites for amplexus and the posterior development of tadpoles.

\section{ACKNOWLEDGEMENTS}

To SISBIO-RAN for the permission to collect and transport biological material (\#44134-1).To the Foundation for Science and Technology of the state of Pernambuco-FACEPE (0287-2.05/14) for the financial aid during the execution of this study.

\section{LITERATURE CITED}

Abrantes SHF, Abrantes MMR, Oliveira JCD, Oliveira WM, Henriques IGN, Silva P F, Chaves, MF (2011) Fauna de anfíbios anuros em três lagoas da área de implantação do Horto Florestal, campus da UFCG, Cuité - PB. Revista Nordestina de Zoologia 5: 19-36. 
AESA (2014) Estações Agro-meteorológicas. Agência Executiva de Águas do Estado da Paraíba. http://pcd.aesa.pb.gov.br [accessed 20 July 2014]

Alves RRN, Mendonça LET, Confwssor MVA, Vieira WLS, Lopez LCS (2009) Hunting strategies used in the semi-arid region of northeastern Brazil. Journal of Ethnobiology and Ethnomedicine 5: 1-50. https://doi.org/10.1186/1746-4269-5-12

Arzabe C (1999). Reproductive activity patterns of anurans in two different altitudinal sites within the Brazilian Caatinga. Revista Brasileira de Zoologia 16: 851-864. https://doi.org/10.1590/ S0101-81751999000300022

Bertoluci J, Rodrigues MT (2002) Seasonal patterns of breeding activity of Atlantic Rainforest anurans at Boracéia, Southeastern Brazil. Amphibia-Reptilia 23: 161-167. https://doi. org/10.1163/156853802760061804

Cardoso AJ, Martins JE (1987) Diversidade de anuros durante o turno de vocalização em comunidades Neotropicais. Papeis Avulsos de Zoologia 36: 279-285.

Cunha ER, Delariva RL (2009) Introdução da rã-touro, Lithobates cetesbeianus (Shaw, 1802): uma revisão. Revista Saúde e Biologia 4: 34-36.

De La Riva I, Maldonado M (1999) First Record of Leptodactylus ocellatus (Linnaeus, 1758) (Amphibia, Anura, Leptodactylidae) in Bolivia and comments on related species. Graellsia 55: 193-197. https://doi.org/10.3989/graellsia.1999.v55.i0.328

Duellman WE, Trueb L (1994) Biology of amphibians. Chicago, Johns Hopkins University press, 696 pp.

Ferreira A, Rosa ABS, Mahmound Mehanna M (2009) Organização celular dos restículos em Hylidae e Leptodactylidae, no Pantanal (Estado do Mato Grosso do Sul, Brasil). Acta Scientiarum, Biological Sciences, 31: 447-452. https://doi.org/10.4025/actascibiolsci.v31i4.3332

Giaretta AA, Menin M, Facure KG, Kokubum MNC, Oliveira Fiho JC (2008) Species richness, relative abundance and habitat of reproduction of terrestrial frogs in the Triângulo Mineiro region, Cerrado biome, Southeastern Brazil. Iheringia, Série Zoologia 98: 181-188. https://doi.org/10.1590/S007347212008000200002

Hally AD (1964) A counting method for measuring the volumes of tissue components in microscopical sections. Quarterly Journal of Microscopical Science 105: 503-17.

Hermosilla IB, Coloma LS, Weigertt GH, Reyes ET, Gomez VO (1986) Caracterizacion Del ovario de la "rana Chilena" Caudiverbera caudiverbera (Linne, 1758) (Anura, Leptodactylidae). Boletin de la Sociedad de Biologia de Concepción 57: 37-47.

Hopwood D (1990) Fixation e fixatives. In: Bancroft JD, Stevens A (Eds) Theory and practice of histological techniques. New York, Churchill Livingstone, $3^{\text {rd }}$ ed., 21-42.

Kalt MR (1976) Morphology and kinetics of spermatogenesis in Xenopuslaevis. Journal of Experimental Zoology 195: 393-408. https://doi.org/10.1002/jez.1401950306

Leite GB, Franco-Belussi L, Provete DB, de Oliveira C (2015) Comparative testis morphology of Neotropical anurans. Zo- ologischer Anzeiger 257: 29-38. https://doi.org/10.1016/j. jcz.2015.04.005

Lofts B (1974) Seasonal changes in the functional activity of the interstitial and spermatogenetic tissues of the green frog, Rana esculenta. General and Comparative Endocrinology 4: 550-562. https://doi.org/10.1016/0016-6480(64)90064-4

Madelaire CB, Gomes FR (2016) Breeding under unpredictable conditions: annual variation in gonadal maturation, energetic reserves and plasma levels of androgens and corticosterone in anurans from the Brazilian Semi-Arid. General and Comparative Endocrinology. https://doi.org/10.1016/j.ygcen.2016.01.011

Mandarim-de-Lacerda CA (1995) Métodos quantitativos em morfologia. Rio de Janeiro, Eduerj, $131 \mathrm{pp}$.

Maragno FP, Cechin S Z (2009) Reproductive biology of Leptodactylus fuscus (Anura, Leptodactylidae) in the subtropical climate, Rio Grande do Sul, Brazil. Iheringia, Série Zoologia, 99: 237241. https://doi.org/10.1590/S0073-47212009000300002

Moore FL, Boydb SK, Kelleyc DB (2005) Historical perspective: Hormonal regulation of behaviors in amphibians. Hormone Behavior48: 373-383. https://doi.org/10.1016/j.yhbeh.2005.05.011

Oliveira C, Vicentini CA, Taboga SR (2003a) Structural characterization of nuclear phenotypes during Scinax fuscovarius spermatogenesis (Anura, Hylidae).Caryologia 56: 75-83. https:// doi.org/10.1080/00087114.2003.10589310

Oliveira C, Sant'anna AC, Omena PM, Santos LRS, Zieri R (2003b) Morphological considerations on the seminiferous structures and testes of anuran amphibians: Bufo crucifer, Physalaemus $\mathrm{cu}$ vieri and Scinax fuscovarius. Biociências 11: 39-46.

Prado CPA, Haddad CFB (2003) Testes size in Leptodactylid frogs and occurrence of multimale spawning in the genus Leptodactylus in Brazil. Journal of Herpetology 37: 354-362. https://doi. org/10.1670/0022-1511(2003)037[0354:TSILFA]2.0.CO;2

Prado CPA,Uetanabaro M (2000)Reproductive biology of Lysapsus limellus Cope, 1862 (Anura, Pseudidae) in the pantanal, Brazil. Zoocriaderos 3: 25-30.

Prado CPA, Uetanabaro M, Haddad CFB (2002) Description of a new reproductive mode in Leptodactylus (Anura, Leptodactylidae), with a review of the reproductive specialization toward terrestriality in the genus. Copeia, 1128-1133. https://doi. org/10.1643/0045-8511(2002)002[1128:DOANRM]2.0.CO;2

Rastogi RK, lela L, Saxena PK, Chieffi G (1976) The control of spermatogenesis in the green frog, Rana esculenta. Journal of Experimental Zoology 196: 151-165. https://doi.org/10.1002/ jez.1401960203

Robinson G, Gray T (1990) Electron microscopy 2: Tissue preparation, sectioning and staining. In: Bancroft JD, Stevens A (Eds) Theory and practice of histological techniques. Edinburgh, $3^{\text {rd }}$ ed., 525-562.

Rodrigues MT (2003) Herpetofauna da caatinga. In: Leal IR, Tabareli M, Silva JMC (Eds) Ecologia e Conservação da Caatinga. Recife, Editora Universitária, 181-236.

Santos, LR, de Oliveira C (2007) Morfometria testicular durante o ciclo reprodutivo de Dendropsophusminutus (Peters) (Anura, 
Hylidae). Revista Brasileira de Zoologia 24: 64-70. https://doi. org/10.1590/S0101-81752007000100008

Santos LR, de Oliveira C (2008) Histological aspects and structural characteristics of the testes of Dendropso phusminutus (Anura, Hylidae). Micron 39: 1266-1270. https://doi.org/10.1016/j. micron.2008.03.006

Sasso-Cerri E, Faria F, Freymuller E, Miraglia SM (2004) Testicular morphological changes during the seasonal reproductive cycle in the Bulfrog Rana catesbiana. Journal of Experimental Zoology, 301A: 249-260. https://doi.org/10.002/jez.a.20023

Villagra ALI, Cisint SB, Crespo CA, Medina MF, Ramos I, Fernández SN (2014) Spermatogenesis in Leptodactylus chaquensis. Histological study. Zygote 22: 2 91-299. https://doi.org/10.1017/ S0967199412000494

Wilczynski W, Lynch KS, O'Bryant EL (2005) Current research in amphibians: Studies integrating endocrinology, behavior, and neurobiology. Hormone Behavior 48: 440-450. https://doi. org/10.1016/j.yhbeh.2005.06.001
Weibel ER (1979) Fleischner Lecture: loocking into the lung: what can tell us? American Journal of Roentgenology 133: 1021-1031. https://doi.org/10.2214/ajr.133.6.1021

Zar JH (1999) Biostatistical analysis. New Jersey, Prentice Hall, 663 pp.

Submitted: 4 July 2016

Received in revised form: 23 September 2016

Accepted: 7 February 2017

Editorial responsibility: Mauricio O. Moura

Author Contributions: MFC, GJBM, AACT idealized the experiment; MFC, FCMAT, VWT, JSB, prepared histological sections and data analysis; MFC, CJCLN collected the animals and prepare the article. Competing Interests: The authors have declared that no competing interests exist. 